\title{
Pelatihan budidaya ikan lele pada kolam terpal dengan sistem akuaponik di Desa Harapan, Kecamatan Sungai Apit, Kabupaten Siak, Provinsi Riau
}

\author{
Mulyadi*, Niken Ayu Pamukas, Adelina, Iesje Lukistyowati, dan Dessy Yoswati \\ Fakultas Perikanan dan Kelautan, Universitas Riau \\ * mulyadibrian26@yahoo.com
}

\begin{abstract}
Abstrak. Mata pencaharian penduduk Kampung Harapan sebagian besar adalah sebagai petani yaitu bertani jagung, ubi, cabe, buah, sayuran (seperti bayam dan kangkung) dan budidaya ikan, prospektif untuk dijadikan lokasi budidaya sistem akuaponik. Teknologi budidaya akuaponik selain menghemat penggunaan lahan dan air, juga meningkatkan efisiensi usaha melalui pemanfaatan hara dari sisa pakan dan metabolisme ikan untuk tanaman sayuran, sehingga mampu memproduksi ikan dan sayuran secara optimal pada lahan sempit dan sumber air terbatas, termasuk di daerah perkotaan. Melalui budidaya sistem akuaponik ini petani budidaya ikan akan mendapatkan dua keuntungan dalam satu tahap produksi. Kegiatan ini dilakukan dengan metode ceramah, diskusi dan praktek, yang bertempat di kantor kepala desa dan pekarangan rumah anggota kelompok petani budidaya ikan Desa Harapan. Kegitan penyuluhan melibatkan pembudidaya ikan, petani perkebunan dan mahasiswa kukerta. Hasil kegiatan pengabdian yang dilakukan menunjukkan terjadi peningkatan keterampilan dan pengetahuan petani mengenai budidaya ikan dengan sistem akuaponik dan pembuatan pelet dengan penambahan temu lawak. Kolam terpal yang digunakan sebagai kolam percontohan memberikan hasil produksi ikan lele dan tanaman kangkung yang cukup tinggi, sehingga dapat menjadi mata pencaharian alternatif bagi petani disamping perkebunan karet dan sawit.
\end{abstract}

Kata kunci: akuaponik; Desa Harapan; lele; pakan; Sungai Apit

\begin{abstract}
Most of the Kampung Harapan residents are farmers, namely farming corn, sweet potatoes, chili, fruit, vegetables (such as spinach and kale) and fish farming. This village is prospective to be used as rearing sites for aquaponic systems. Aquaponic cultivation technology can be developed in limited area and water, and it also can increase business efficiency through the utilization of nutrients from the uneaten fish meal and the metabolism wastes of fish for vegetables, so it could be able to produce fish and vegetables optimally on narrow land and limited water sources, including in urban areas. Through the fish rearing with aquaponic systems, fish farmers will get two advantages in one production stage. This activity was carried out through discussion and practice, which the activity took place in the village office and in the home yard of the fish farmer group in Harapan Village. Extension activities involve fish farmers, plantation farmers and several students. The results of the activities showed that skills and knowledge of fish farmers increase regarding aquaponics fish farming and making pellets mix with gingger. Plastic fish ponds as a pilot project produce high yields of catfish and leafy vegetables, so it can be an alternative income for fish farmers.
\end{abstract}

Keywords: aquaponic; catfish; fish meal; Desa Harapan; Sungai Apit

To cite this article: Mulyadi, N. A. Pamukas, Adelina, I. Lukistyowati, \& D. Yoswati. 2019. Pelatihan budidaya ikan lele pada kolam terpal dengan sistem akuaponik di Desa Harapan, Kecamatan Sungai Apit, Kabupaten Siak, Provinsi Riau. Unri Conference Series: Community Engagement 1: 347-354 https://doi.org/10.31258/unricsce.1.347-354

(C) 2019 Authors

Peer-review under responsibility of the organizing committee of Seminar Nasional Pemberdayaan Masyarakat 2019 


\section{PENDAHULUAN}

Desa Harapan merupakan salah satu desa di Kecamatan Sungai Apit Kabupaten Siak dengan luas daerah 1.670 ha. Topografi Kecamatan Sungai Apit terdiri dari tanah datar sampai berombak, dengan ketinggian tanah 26 $\mathrm{m}$ dari permukaan laut. Jenis tanah di desa ini hitam gembur dengan curah hujan berkisar $3.487 \mathrm{~mm} / \mathrm{tahun}$ dan suhu $20-80^{\circ} \mathrm{C}$. Desa Harapan merupakan salah satu bagian dari kecamatan Sungai Apit yang diairi oleh Sungai Siak yang dapat digunakan sebagai sumber air untuk kegiatan budidaya ikan (Badan Pusat Statistik Kabupaten Siak, 2018).

Mata pencaharian penduduk Desa Harapan sebagian besar adalah sebagai petani jagung, ubi, cabe, buah, sayuran (seperti bayam dan kangkung) dan menangkap ikan di Sungai Siak. Seluruh penduduk Desa Harapan masih memilih dan bergantung dengan mata pencaharian bertani dibandingkan melakukan kegiatan budidaya ikan. Kegiatan budidaya ikan hanya dilakukan oleh 2 orang penduduk yaitu Bapak Kepala Desa dan Bapak BPD. Ikan yang dibudidayakan adalah ikan Patin (Pangasius sp.) dan ikan Lele (Clarias sp.). Dewasa ini permintaan pasar terhadap ikan sebagai sumber protein pangan relatif tinggi, namun pemasokan ikan ke pasar hanya berasal dari hasil tangkapan sungai sehingga tidak dapat memenuhi permintaan pasar. Untuk itu harus dilakukan usaha untuk membuat masyarakat sadar akan pentingnya budidaya ikan yang dapat dikembangkan bersamaan dengan kegiatan bercocok tanam atau bertani sayuran.

Tingginya permintaan pasar untuk kebutuhan ikan terutama ikan lele dan juga keinginan masyarakat yang masih ingin bertanam sayuran menjadikan budidaya ikan lele dengan sistem aquaponik yang dilakukan di desa ini merupakan suatu kegiatan usaha yang memiliki prospek yang baik dan layak untuk dikembangkan ditinjau dari aspek pasar, aspek teknis dan aspek finansial. Ditinjau dari aspek pasar, usaha budidaya lele berpotensi untuk dikembangkan karena tingginya permintaan pasar. Ditinjau dari aspek teknis, budidaya lele dapat dikembangkan karena dapat dilakukan pada lahan sempit/ pekarangan rumah, tingkat teknologi yang digunakan cukup sederhana sehingga dapat diterapkan oleh petani, sarana dan prasarana pendukung budidaya secara umum mudah didapat atau bisa dimodifikasi, dan nilai tambah produk dapat ditingkatkan melalui teknis budidaya yang dapat diterapkan di tingkat petani. Dengan kata lain budidaya ikan sistem akuaponik dapat memproduksi sayur dan ikan dalam satu siklus panen (Diver, 2006; Siswadi dan Yuwono, 2013), sehingga masyarakat Desa Harapan akan mendapatkan dua keuntungan dalam satu tahap produksi.

Kegiatan budidaya ikan lele juga membutuhkan pakan berkualitas baik untuk dapat mempercepat pertumbuhan ikan dalam waktu relatif singkat. Harga pakan ikan komersil (pakan pabrik) saat ini relatif mahal. Untuk mengantisipasinya maka perlu dilakukan pembuatan pakan ikan secara mandiri yaitu memanfaatkan bahan-bahan baku lokal yang kualitasnya baik seperti: bekicot/keong mas, ampas tahu (Adelina dan Boer, 2011), biji karet (Adelina dan Boer, 2015), dedak dan limbah bulu ayam potong (Adelina et al., 2017) sehingga penyediaan biaya operasional dapat lebih efisien.

Berdasarkan uraian di atas maka melalui kegiatan pengabdian kepada masyarakat, Tim dari Fakultas Perikanan dan Kelautan Universitas Riau melakukan inovasi pengetahuan dan wawasan di bidang budidaya ikan lele menggunakan aplikasi teknik akuaponik dan pembuatan pakan berbasis bahan lokal di desa Harapan Kecamatan Sungai Apit Kabupaten Siak. Kegiatan Pengabdian yang dilakukan Tim terhadap pembudidaya ikan bertujuan untuk menambah pengetahuan dan keterampilan kepada petani ikan tentang: 1). inovasi di bidang teknik budidaya ikan lele dengan sistem akuaponik. Dengan dikuasainya dan diterapkannya pengetahuan mengenai budidaya akuaponik diharapkan petani mampu memanfaatkan pekarangan rumah sendiri, sehingga penggunaan lahan dan air dapat diminimalisir. Tingginya keuntungan produksi yang didapat pada akhirnya akan dapat meningkatkan pendapatan masyarakat Desa Harapan. 2). Teknik membuat pelet berkualitas baik dengan memanfaatkan bahan-bahan lokal untuk menghasilkan pelet yang murah harganya dan mampu mempercepat pertumbuhan ikan. Terlaksananya kegiatan ini diharapkan dapat membantu masyarakat memproduksi ikan lele secara mandiri dan dapat memenuhi permintaan pasar serta dapat meningkatkan kesejahteraan petani.

\section{PERMASALAHAN}

Dewasa ini permintaan pasar terhadap ikan lele di Desa Harapan relatif tinggi, hal ini disebabkan kebutuhan masyarakat pada protein yang bersumber dari ikan semakin tinggi. Ketersediaan ikan lele selama ini masih mengandalkan hasil tangkapan perairan alam. Masyarakat setempat belum ada yang melakukan budidaya ikan lele. Lahan yang mereka miliki lebih banyak digunakan untuk bertanam sayur. Padahal lahan pekarangan tersebut prospektif untuk dijadikan wadah budidaya ikan lele sekaligus bertanam sayur melalui teknologi budidaya akuaponik. Keunggulan budidaya ikan sistem akuaponik adalah dapat menghemat penggunaan lahan 
dan air, serta dapat memproduksi sayur dan ikan dalam satu siklus panen sehingga akan mendapatkan dua keuntungan dalam satu tahap produksi.

Budidaya ikan juga dihadapkan pada tingginya harga pakan pabrik sehingga biaya operasional akan relatif tinggi jika mengandalkan pakan tersebut. Harga pakan (berupa pelet) tersebut saat ini berkisar Rp.10.000$12.000 / \mathrm{kg}$. Untuk mengurangi biaya pembelian pelet pabrik, petani dapat memberikan pelet buatan sendiri yaitu dengan memanfaatkan bahan-bahan lokal yang kualitasnya baik seperti: bekicot/keong mas, ampas tahu (Adelina dan Boer, 2011), biji karet (Adelina dan Boer, 2015), dedak dan limbah bulu ayam potong (Adelina, Aryani dan Lukistyowati, 2017) sehingga pelet yang dihasilkan juga berkualitas baik dan tidak kalah dengan pakan komersil bahkan harganya relatif murah (Rp. 3.500-4.000/kg), jauh lebih murah dibandingkan pakan komersil. Melalui kegiatan pengabdian kepada masyarakat, telah dilakukan inovasi pengetahuan tentang teknik budidaya ikan sistem akuaponik dan pembuatan pelet berkualitas baik yang murah harganya di Desa Harapan Kecamatan Sungai Apit Kabupaten Siak.

\section{METODE PENERAPAN}

Kegiatan pengabdian kepada masyarakat ini dilakukan selama 6 (enam) bulan yang dimulai dari survey lokasi hingga terlaksananya kegiatan. Masyarakat yang dijadikan sasaran kegiatan adalah petani di Desa Harapan yang mempunyai mata pencaharian utama sebagai petani jagung, ubi, buah, sayur serta peternak ayam dan itik.

Kegiatan ini dilaksanakan dengan cara sebagai berikut:

1. Penyampaian materi

Materi disampaikan dengan metode ceramah yaitu tentang budidaya ikan lele sistem akuaponik dan pembuatan pakan ikan berbasis bahan-bahan lokal. Sebelum materi disampaikan, terlebih dahulu dibagikan hand out untuk memudahkan petani memahami materi yang akan disampaikan. Kegiatan ini dilakukan di ruang pertemuan kantor kepala Desa Harapan.

Materi yang disampaikan untuk budidaya ikan lele sistem akuaponik adalah:

a. Keunggulan budidaya ikan dengan sistem akuaponik serta teknik pembuatannya (Ahmad et al., 2007).

b. Tanaman yang dapat digunakan pada budidaya ikan sistem akuaponik (Siswadi dan Yuwono, 2013)

c. Ikan lele dan keunggulannya serta pakan untuk ikan tersebut

Materi yang disampaikan untuk pembuatan pakan ikan adalah:

a. Bahan-bahan lokal berkualitas baik yang ada di sekitar petani yang dapat dijadikan bahan baku pelet seperti: ampas tahu, dedak, limbah rumah potong, bekicot, keong mas dan ikan rucah serta kandungan nutrien setiap bahan (Hertrampf and Pascual, 2000).

b. Bahan-bahan alami yang dapat meningkatkan kesehatan ikan seperti: bawang putih, kunyit, temulawak yang dapat dicampur dengan pakan ikan (Lukistyowati, 2008).

c. Cara mempersiapkan/mengolah bahan-bahan pakan hingga menjadi tepung.

d. Cara memformulasi pelet dengan komposisi bahan dan kandungan nutrien yang memenuhi kebutuhan ikan, dengan metoda bujursangkar (NRC, 1993).

e. Cara menghitung biaya pembuatan pelet (Adelina, Boer dan Suharman, 2009; NRC, 1993).

f. Cara mencetak pelet yang baik dan benar, cara menjemur pelet yang telah jadi dan cara mengemas dan menyimpan pelet yang telah kering.

g. Cara menghitung banyaknya pakan yang diberikan ke ikan dan frekwensi pemberian pakan serta cara memberikan pakan ke ikan budidaya dengan benar selama masa pemeliharaan (NRC, 1993).

h. Cara menghitung pertumbuhan/produksi ikan.

2. Diskusi atau tanya jawab

Diskusi atau tanya jawab dilakukan terhadap materi yang kurang dipahami. Adanya pertanyaan dari peserta berarti ada feedback dari peserta sehingga diharapkan pemahaman terhadap materi yang diberikan akan lebih baik. 
3. Demonstrasi atau Praktek

Peningkatan keterampilan petani ikan dilakukan dengan mengajak petani melakukan praktek pembuatan kolam akuaponik yang dilakukan di halaman rumah kepala desa dan pembuatan pakan ikan dilakukan di ruang pertemuan kantor kepala desa.

Terlaksananya kegiatan pengabdian kepada masyarakat ini diharapkan dapat meningkatkan pengetahuan, keterampilan dan motivasi para petani di Desa Harapan sehingga petani mampu memproduksi ikan lele dengan pemberian pakan buatan sendiri dengan biaya yang relatif murah untuk tujuan meningkatkan pendapatan atau kesejahteraan petani.

\section{HASIL DAN KETERCAPAIAN SASARAN}

\section{Penyajian Materi Penyuluhan}

Kegiatan pengabdian kepada masyarakat diawali dengan pembukaan oleh kepala Desa Harapan, kemudian perkenalan anggota Tim terhadap peserta/petani (Gambar 1). Selanjutnya dilakukan penyampaian materi tentang: Teknik Budidaya Ikan Lele Dengan Sistem Akuaponik dan Pembuatan Pakan Ikan Berupa Pelet (Gambar 2). Setelah penyampaian materi dilanjutkan dengan sesi diskusi, pada sesi diskusi peserta penyuluhan antusias mengajukan pertanyaan mengenai materi yang kurang dimengerti dan permasalahan yang mungkin dihadapi pada budidaya ikan.

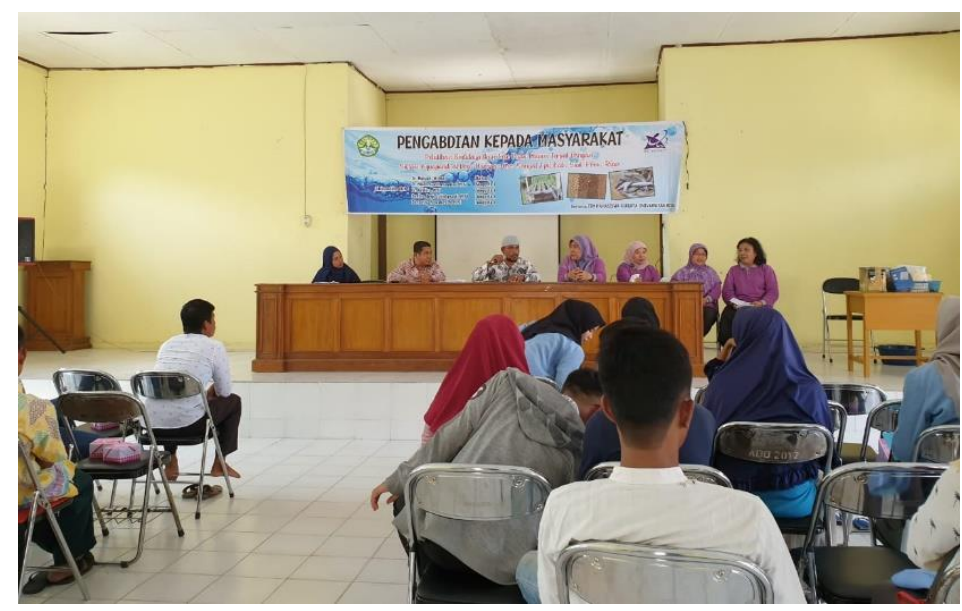

Gambar 1. Pembukaan kegiatan pengabdian kepada masyarakat oleh kepala Desa Harapan
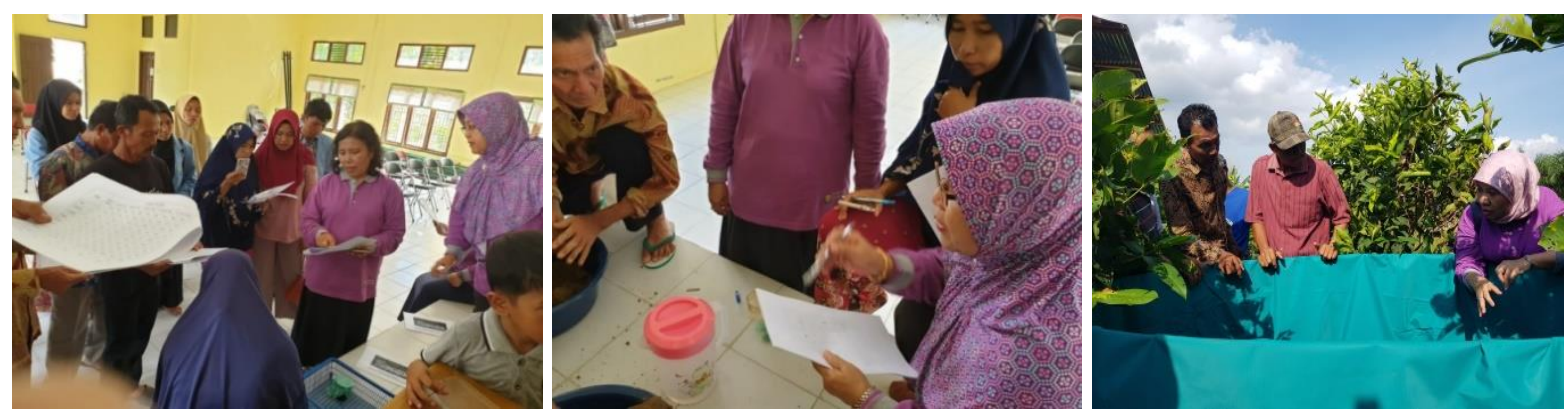

Gambar 2. Penyajian materi penyuluhan oleh anggota Tim

\section{Demonstrasi dan Praktek Budidaya Ikan Lele Sistem Akuaponik}

Teknik budidaya ikan dengan sistem akuaponik melibatkan dua komponen budidaya, yakni ikan lele dan tanaman cabe. Kegiatan ini dilakukan dengan tahapan sebagai berikut: 


\section{Persiapan Wadah}

Wadah yang digunakan untuk pemeliharaan ikan lele adalah kolam terpal berbentuk bulat dengan diameter $1,75 \mathrm{~m}$ dan tinggi $1 \mathrm{~m}$ serta volume air yang diisi 1000 liter. Pada keliling atas kolam terpal diletakkan pot-pot yang berisi tanaman cabe. Untuk mengairi air dari kolam terpal ke wadah tanaman cabe digunakan pompa air kekuatan 25 watt (Gambar 3).
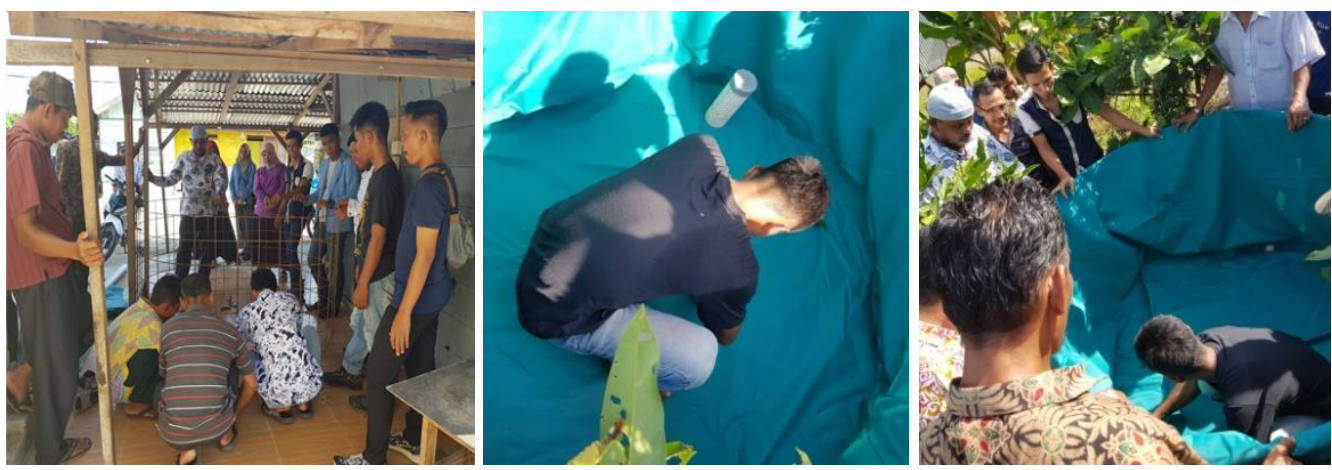

Gambar 3. Kolam terpal untuk pemeliharaan ikan lele

\section{Penebaran Benih}

Ikan yang ditebar ke kolam terpal adalah ikan lele dumbo ukuran 3-4 cm. Sebelum benih ditebar pada wadah pemeliharaan, terlebih dahulu benih diadaptasikan agar tidak stres dan mampu menyesuaikan diri dengan lingkungan pemeliharaan. Benih ikan lele yang akan ditebar terlebih dahulu diseleksi dengan kriteria berbadan sehat, tidak cacat, pergerakan lincah, dan warna cerah. Banyaknya benih lele yang ditebar adalah 1000 ekor/ $1000 \mathrm{~L}$ air (Gambar 4).
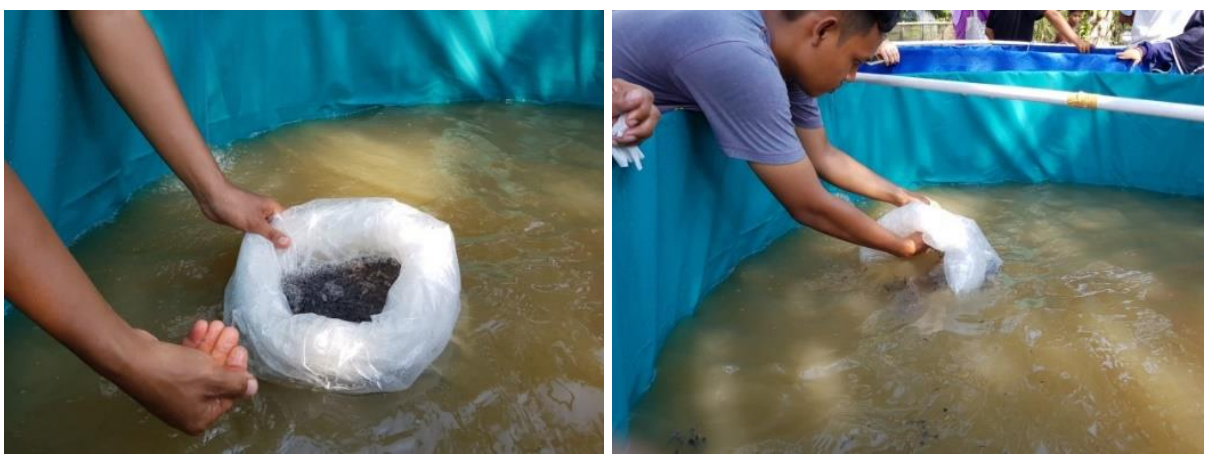

Gambar 4. Penebaran benih ikan lele dumbo

\section{Penanaman Tanaman Cabe}

Tanaman yang digunakan pada budidaya ikan lele sistem akuaponik ini adalah cabe. Sebelum tanaman cabe ditanam pada pot terlebih dahulu benih cabe disemai, setelah berumur 1 bulan dan sudah memiliki 3-4 helai daun selanjutnya tanaman cabe dipindahkan ke dalam pot. Setiap 1 pot diisi dengan 1 batang tanaman cabe (Gambar 5).
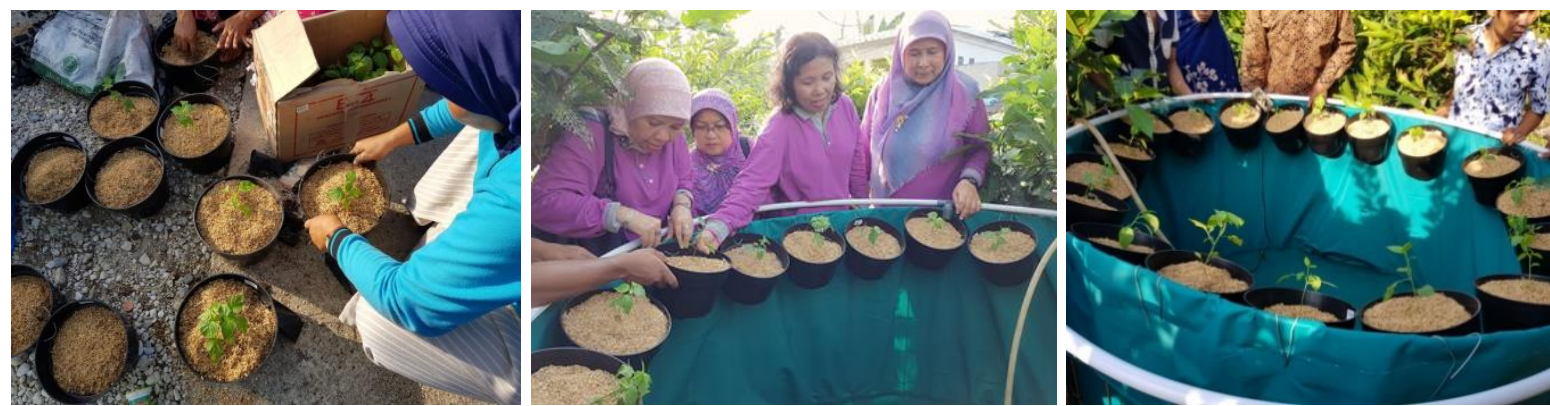

Gambar 5. Penanaman tanaman cabe dan peletakannya di sekeliling kolam terpal

Budidaya ikan sistem akuaponik merupakan sistem budidaya yang hemat air dan dapat dilakukan di lingkungan halaman rumah. Air yang berasal dari wadah pemeliharaan ikan lele akan disirkulasi ke 
tanaman cabe untuk difilter sehingga amoniak yang berasal dari sisa pakan dan feses ikan akan dirombak dan difilter tanaman cabe dan dapat digunakan kembali untuk memelihara ikan. Diver (2006) menyatakan sistem sirkulasi merupakan salah satu cara untuk memperbaiki kualitas air sebagai media pemeliharaan ikan dalam kegiatan budidaya. Sirkulasi air dapat membantu distribusi oksigen ke segala arah baik di dalam air maupun difusinya atau pertukaran dengan udara dan dapat menjaga akumulasi atau mengumpulnya hasil metabolisme beracun sehingga kadar racun dapat dikurangi.

\section{Demonstrasi dan Praktek Pembuatan Pakan Ikan Berupa Pelet}

Praktek pembuatan pelet dilakukan dengan melibatkan seluruh peserta untuk berperan aktif terhadap kegiatan yang dilaksanakan dan dipandu oleh Tim. Pada sesi ini diajarkan dan dipraktekkan tentang:

\section{Formulasi bahan pakan}

Pakan yang akan dibuat terlebih dahulu disusun formulasinya. Bahan-bahan pakan yang digunakan adalah tepung ikan, tepung kedelai dan tepung biji karet sebagai sumber protein, dedak padi dan tepung terigu sebagai sumber karbohidrat, minyak ikan sebagai sumber lemak, kemudian vitamin dan mineral. Semua bahan pakan diatur jumlahnya sesuai kebutuhan ikan lele dan mempunyai kandungan protein $35 \%$ (Gambar 6).
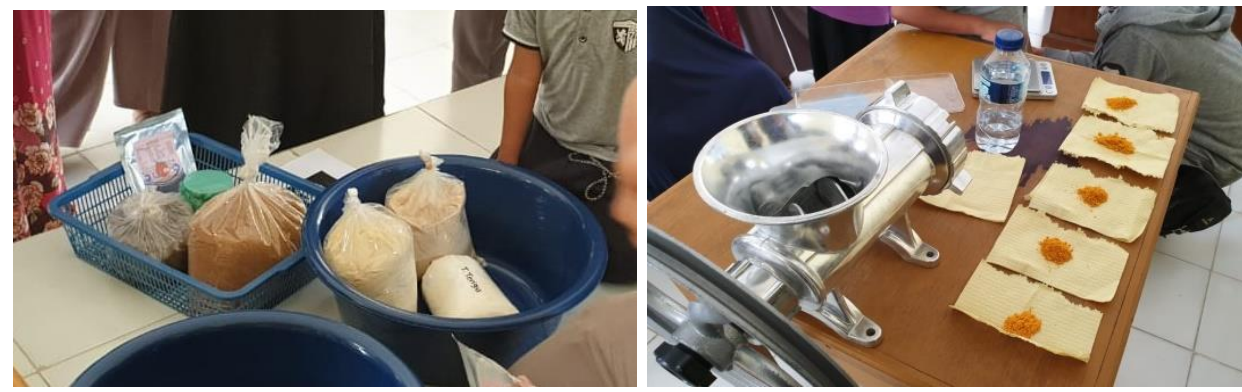

Gambar 6. Bahan-bahan pakan ikan lele

\section{Pencampuran bahan-bahan pakan}

Bahan-bahan pakan yang digunakan untuk pembuatan pakan dicampur mulai dari bahan yang jumlahnya sedikit hingga jumlah yang paling banyak. Pencampuran bahan dilakukan hingga semuanya tercampur homogen (Gambar 7).
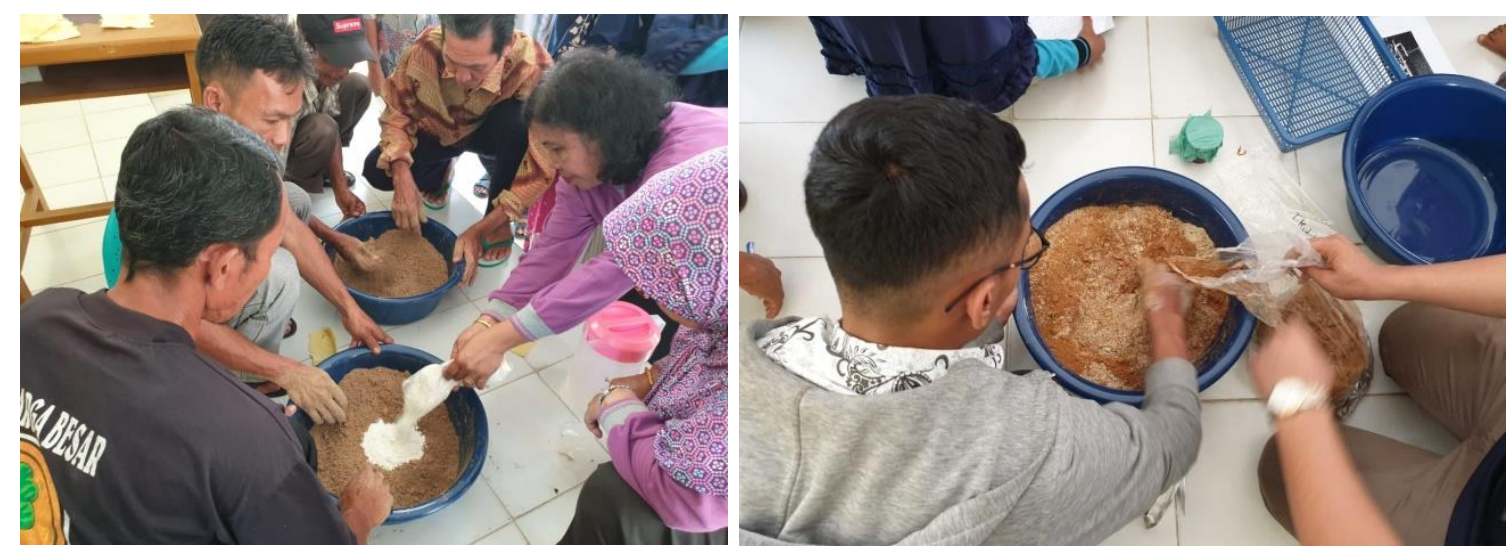

Gambar 7. Pencampuran bahan-bahan pakan

\section{Pencetakan dan pengeringan pelet yang telah jadi}

Bahan-bahan pakan yang telah tercampur homogen selanjutnya dicetak menjadi pelet menggunakan alat pencetak pelet. Pelet yang telah jadi kemudian dijemur di bawah matahari hingga kering. Penjemuran bertujuan agar pelet tidak berjamur dan dapat disimpan dalam jangka waktu lebih lama (Gambar 8 dan Gambar 9). 


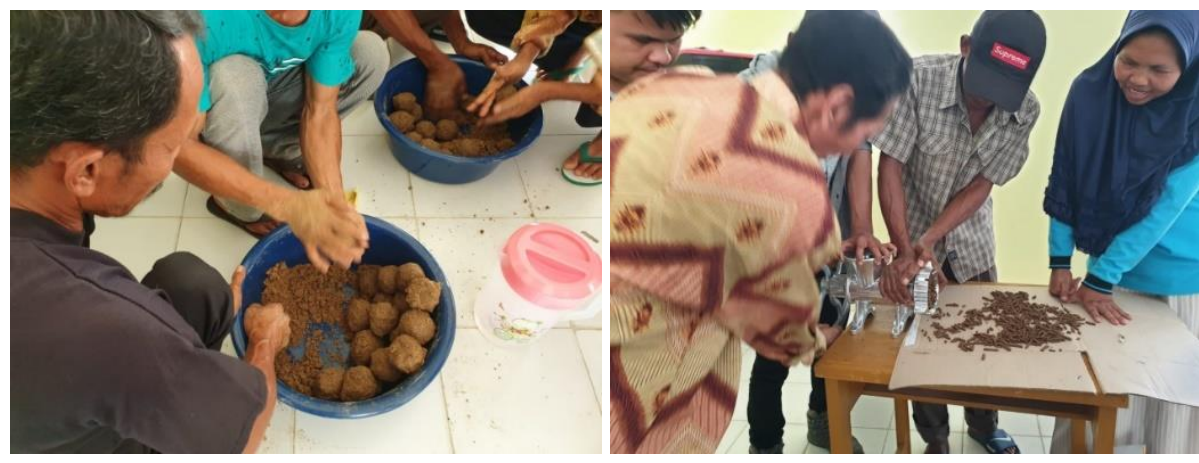

Gambar 8. Pencetakan pakan ikan berupa pelet

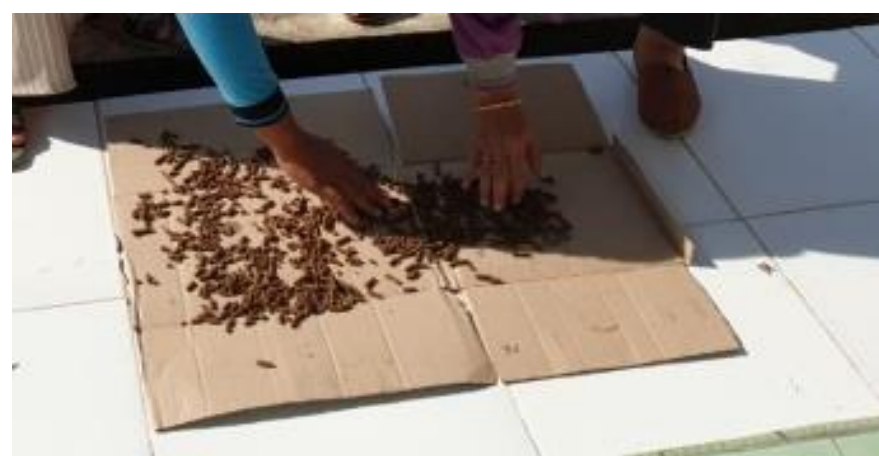

Gambar 9. Penjemuran pelet yang telah jadi

Pelet yang dibuat petani mempunyai kualitas baik karena dibuat dari bahan-bahan yang berkualitas baik seperti tepung ikan, tepung kedelai, tepung biji karet, dedak, terigu, vitamin dan mineral mix serta minyak ikan, kemudian juga disusun dengan kandungan nutrien (protein, lemak dan karbohidrat) yang memenuhi kebutuhan ikan. Hal ini sesuai dengan yang dikemukakan NRC (1993) yang menjelaskan bahwa pakan harus mengandung nutrien maupun energi yang diperlukan ikan untuk pertumbuhan dan kesehatan ikan. Pelet tersebut juga mempunyai harga relatif murah (Rp. 4.500-5.000/kg) dibandingkan pelet komersil yang harganya berkisar Rp. 12.000-13.000/kg. Pelet yang telah dihasilkan kemudian diuji kualitasnya. Kualitas fisik pelet yang telah dibuat petani tergolong baik, karena pelet dijemur dengan baik, kemudian pelet dapat disimpan lama dan tidak ditumbuhi jamur. Pelet juga dapat menggumpal dengan baik sehingga tidak mudah pecah di dalam air. Pelet kemudian diberikan ke ikan lele dumbo secara add satiation (sampai ikan kenyang). Frekuensi pemberian pakan 3 kali sehari yaitu pukul 08:00, 12:00 dan 16:00 WIB.

Kegiatan pengabdian kepada masyarakat yang telah dilakukan memberi banyak perubahan pada peserta terutama peningkatan pengetahuan/wawasan dan keterampilan serta sikap peserta yang kelihatan dari motivasi/ antusias untuk turut praktek melakukan kegiatan. Hasil evaluasi menunjukkan bahwa terjadi peningkatan pengetahuan dan keterampilan peserta sekitar $85 \%$ terhadap budidaya ikan lele sistem akuaponik dan $75 \%$ terhadap pembuatan pakan ikan. Peningkatan pengetahuan dan keterampilan yang terlihat adalah meliputi:

1. Peserta memahami keunggulan dan manfaat budidaya ikan sistem akuaponik,

2. Peserta memahami pentingnya menjaga kualitas air budidaya agar ikan yang dibudidayakan tidak terhambat pertumbuhannya dan dapat dipanen tepat waktu.

3. Peserta memahami bahwa budidaya ikan tidak hanya fokus pada output ikan, melainkan juga bisa memanen cabe.

4. Peserta penyuluhan dapat membuat sendiri konstruksi sistem akuaponik dan dapat mengoperasikannya.

5. Peserta memahami bahwa ikan membutuhkan pakan berkualitas untuk dapat hidup dan bertumbuh.

6. Peserta memahami bahwa pakan dapat dibuat dari bahan-bahan lokal yang ada di lingkungan sekitar yang murah harganya.

7. Peserta memahami cara mencampur bahan-bahan pakan dan antusias untuk membuat pelet dengan cara yang baik untuk mendapatkan pelet berkualitas baik.

8. Peserta memahami cara memberi pakan ke ikan dengan jumlah yang cukup. 


\section{KESIMPULAN}

Serangkaian kegiatan pengabdian kepada mastarakat yang telah dilakukan mengenai teknik budidaya ikan lele di kolam terpal dengan sistem akuaponik dan pembuatan pakan ikan berbasis bahan lokal telah terlaksana dan berlangsung dengan baik. Inovasi pengetahuan telah mampu diterima dengan baik, bahkan dapat meningkatkan pengetahuan dan keterampilan petani Desa Harapan. Peningkatan pengetahuan dan keterampilan petani serta motivasi sangat diharapkan untuk dapat menjadi bekal agar kegiatan budidaya ini dapat terus berlanjut dan Desa Harapan dapat menjadi desa percontohan teknik budidaya ikan dengan sistem akuaponik dan pembuatan pakan berupa pelet untuk beberapa tahun ke depan. Budidaya ikan merupakan hal baru bagi petani Desa Harapan sehingga mungkin tidak dapat langsung diaplikasikan, kemudian mereka juga mengalami kendala keuangan untuk menyediakan semua fasilitas yang diperlukan untuk budidaya ikan. Oleh karena itu pada saat melakukan kegiatan, Tim memberikan bantuan berupa kolam terpal, benih ikan lele dan alat pencetak pelet dengan harapan memberi motivasi kepada petani setempat. Jika kegiatan budidaya telah berhasil dan berkembang dilakukan masyarakat Desa Harapan, maka kegiatan pengabdian masyarakat berikutnya yang dapat dilakukan adalah teknik pembenihan ikan lele sehingga masyarakat setempat dapat menyediakan benih secara mandiri. Kegiatan lain yang dapat dilakukan adalah teknik pengelolaan kualitas air media budidaya ikan seperti sistem pengairan kolam yang baik sehingga didapatkan kualitas air optimal untuk meningkatkan kelulushidupan dan pertumbuhan ikan.

\section{UCAPAN TERIMA KASIH}

Terlaksanya kegiatan pengabdian kepada masyarakat di Desa Harapan tidak terlepas dari kerjasama Tim dengan LPPM Universitas Riau, untuk itu Tim mengucapkan terimakasih karena LPPM Universitas Riau telah memberi bantuan dana sehingga kegiatan telah terlaksana dengan baik. Ucapan terimakasih juga disampaikan kepada aparat Desa Harapan yang telah dapat menerima Tim untuk dapat melaksanakan kegiatan ini.

\section{DAFTAR PUSTAKA}

Adelina, dan I. Boer. 2011. Pemanfaatan Kepala Udang dan Ampas Tahu Sebagai Pengganti Tepung Ikan dalam Pakan Benih Ikan Selais (Ompok hypopthalmus). Prosiding Seminar Antarbangsa ke 4 Ekologi, Habitat Manusia dan Perubahan Persekitaran di Alam Melayu. hal 966-976.

Adelina, dan I. Boer. 2015. Pengaruh Penggunaan Biji Karet (Havea brasiliensis) Dalam Pakan Terhadap Pertumbuhan Gurami Ikan gurami (Osphronemus gouramy). Laporan Penelitian. Lembaga Penelitian dan Pengabdian Kepada Masyarakat. (tidak diterbitkan).

Adelina, N. Aryani, dan I. Lukistyowati. 2017. Pemanfaatan Bulu Ayam Sebagai Sumber Protein Pengganti Tepung Ikan Dalam Pakan Ikan Kakap Putih (Lates calcarifer, Bloch). Laporan Penelitian. 58 hlm (tidak diterbitkan).

Ahmad, T., L. Sofiarsih, dan Rusmana. 2007. The growth of Patin (Pangasius hypopthalmus) in a close system tank. Journal Aquaculture 2(1): 67-73.

Badan Pusat Statistik Kabupaten Siak. 2018. Kecamatan Sungai Apit Dalam Angka. Badan Pusat Statistik Kabupaten Siak.

Diver S. 2006. Aquaponics-Integration of Hydroponics with Aquaculture. National Sustainable Agriculture Information Service, Australia.

Hertrampf, J. W., and F. Piedad-Pascual. 2000. Handbook on ingredients for aquaculture feeds. London: Kluwer Academic Publishers.

Lukistyowati, I. 2008. Studi Efektivitas Bawang Putih (Allium sativum) Untuk mencegah dan mengobati Penyakit Motile Aeromonas Septicemia pada Ikan Mas (Cyprinus carpio L). Jurnal Perikanan 10(1): 10-16.

NRC, National research Council. 1993. Nutrient requirement of fish. National Academy of Science. Washington, D.C.

Siswadi dan T. Yuwono, 2013, Uji Hasil Tanaman Sawi Pada Berbagai Media Tanam Secara Hidroponik. Jurnal Innofarm 2(1): 44-50. 